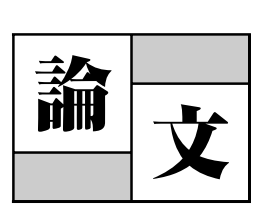

\title{
複雑形状射出成形品に生じるそり発生メカニズムに関する研究
}

\author{
佐 藤和 人 $^{* 1} \cdot$ 和田卓 也 ${ }^{* 2} \cdot$ 山部昌*2
}

\section{Mechanism of Warpage Generation in Injection Molding for a Product with a Complex Shape}

\begin{abstract}
Satoh, Kazuhito*1/Wada,Takuya*1/Yamabe, Masashi*2
Injection molding has been widely used because of its versatility in fabricating complex shapes in a single process. Part warpage, however, is sometimes a problem with injection molding, hence many studies have been performed on understanding the mechanisms of warpage. Most of these studies have investigated simple injection molded shapes. In this report, the warpage generation mechanism was considered for a complex shape with the following results obtained:

1) Warpage was measured for injection molded plates with a variety of shapes. The greatest warpage was found in the plate with a rib.

2 ) The high warpage for the plate with the rib is due to large material property variations.

3 ) Very complex melt flow behavior, such as diverging flow, micro flow and accelerating flow, were observed in the vicinity of the rib. This complex melt flow was responsible for the strong location dependence in material properties near the rib.

4) Warpage in the parts with a complex shape is caused not only by the thermal-induced stresses but also by the flow-induced stresses.
\end{abstract}

Key words : Injection molding/Warpage/Complex shape/Thermal expansion coefficient/ Visualization experiment

\section{1. 緒言}

射出成形法は短時間に同一形状を大量生産できることか ら広く用いられる熱可塑性樹脂の成形法の一つである。熱 可塑性樹脂は鉄鋼などと比較し，融点が遙かに低く成形が 容易であるため, 成形性が良く, 複雑形状の成形も可能と なる.よって, 部品の一体化により加工工程並びに加工コ スト, 組立工数は低減される. 更に比重も約 $0.9 \sim 1.5$ と

\footnotetext{
*1 ムネカタ(秼) R\&D センター 福島市蓬莱町 1-11-1（９600-8506）

Research \& Development center, Munekata Co., Ltd. 1-11-1, Hourai-cho, Fukushima 960-8506, Japan

*2 金沢工業大学工学部機械工学科

白山市八束穂 3-1 石川リサーチパーク内（９24-0838）

Department of Mechanical Engineering, Kanazawa Institute of Technology

3-1, Yatsukaho, Hakusan 924-0838, Japan

2005. 12.26 受理
}

小さく, 自動車や航空機部品の軽量化に大きく貢献出来る.

しかし，その一方で，射出成形品はそり，ひけ，ウェル ドラインといった成形不良が発生しやすい. 中でもそり変 形は部品の寸法精度に大きな影響を与え，品質低下を招く ため, 射出成形品の品質向上にはそり変形を抑制すること が重要な課題となる.

このような射出成形品に生じる成形不良は近年，射出成 形 CAE を用いた事前予測による対策が行われる。しかし， 現状の射出成形 CAEのそり解析精度は実用上, 十分とは 言い難い. 原因はそり量やそり変形のモードが材料や形状, 成形条件により異なる場合があり，そり発生メカニズムが 十分解明されていないことが要因の一つである.よって, 射出成形 CAEのそり解析精度向上には形状や成形条件に よって変化する様々なそり発生メカニズムを明らかにする 必要がある。

射出成形品に生じるそり変形は一般に残留応力の解放に より 発生する ${ }^{1)}$. その残留応力の発生要因は(1)流動要因, (2)熱的要因の二つに分類される. 流動力要因は流動によっ 
て成形板内に配向度合いの分布が生じることに起因する。 成形過程中の樹脂は表層と内部で冷却速度の違いが発生し, 樹脂流速差が生じる。この流速差によってせん断力が生じ る. せん断力を受けた分子鎖は配向し, 配向した分子鎖は 安定した状態に戻ろうとするため, 冷却過程時中に配向緩 和が発生する．表層の分子鎖は配向したまま固化するため， 配向度合いは大きくなるのに対し, 内部の分子鎖は固化前 に緩和するため, 配向は小さくなる.この配向度の分布が 線膨張係数の異方性に分布を与え, そり変形が発生する.

一方, 熱的要因は成形板内の冷却速度差により, 収縮量 に分布が生じるため，そり変形が発生する。

実際の射出成形品に生じる残留応力は流動要因と熱的要 因が複合し発生する ${ }^{2}$. また，これまでの研究例では，流 動要因がそり変形に与える影響は小さいとされている ${ }^{3)}$.

これまでのそり変形や残留応力に関する報告例は平板や 円盤など単純形状での検討が多( ${ }^{4)}$ ）．しかし，実際の射 出成形部品はリブ, ボス, 偏肉などを有した 3 次元形状と なる. 平板形状の場合, 樹脂流動は成形板内で対称な流動 となり ${ }^{8)}$, 流動方向は変化しない。一方，実際の部品では， 樹脂流動は分岐流を伴う等，流動方向が場所により異なる. また，局所的な熱だまりが発生する場合があるため，実部 品では平板形状と比較し, そり発生メカニズムは複雑にな ることが予想される.よって, 更に射出成形 CAEにおけ るそり解析精度を向上させるためには，このような実部品 を想定したモデルでそり発生メカニズムを解明することが 必要であると考えられる.

実部品のそり変形やひけに関する研究は高原 ${ }^{9} ら$ 竹内 ${ }^{10)}$ によって報告されている. 高原は自動車用インストルメン トパネルのそり量と加熱収縮やクリープ特性を考慮した構 造解析結果の比較を行い, 熱変形挙動の予測手法を提案し た。一方, 竹内はボディーパネルの開発において, リブ部 のひけを定量評価し，ひけの低減方法を検討した。しかし， 実部品の場合，樹脂流動方向や肉厚が場所により異なる等， 試験片採取箇所や試験片採取方法の問題が生じる。よって, 成形板の物性值分布の測定は難しく，高原らのようにテス トピースに生じる物性值分布を代用し, 解析を行っている のが現状である，実部品を想定した形状を用いて，そり変 形に関する研究も行われているが11) 13), 未だその研究例は 少ない. 更に実部品を想定した形状で成形板内に生じる物 性值分布を測定し，そり変形との関係を検討した例はほと んど無いのが現状である.

本論文では実部品のような複雑形状射出成形品に構成さ れる代表的な形状要素を抽出し, 各々の形状要素に分割し たテストピースを用い, 射出成形品に生じるそり発生メカ ニズムの検討を行った。

\section{2. 各形状におけるそり量測定}

\section{1 成形板形状および成形条件}

前述の通り, 実部品におけるそり発生メカニズムを検討 する場合, そり発生メカニズムの複雑化, 樹脂流動方向が 場所により異なり, 試験片採取箇所や採取方法等が問題と なる，そこで，本論文では実際の部品に構成される代表的 な形状要素を抽出したテストピースを試作し, 検討を行っ た. 例えば, 自動車用バンパーの場合, 薄肉化に伴う強度

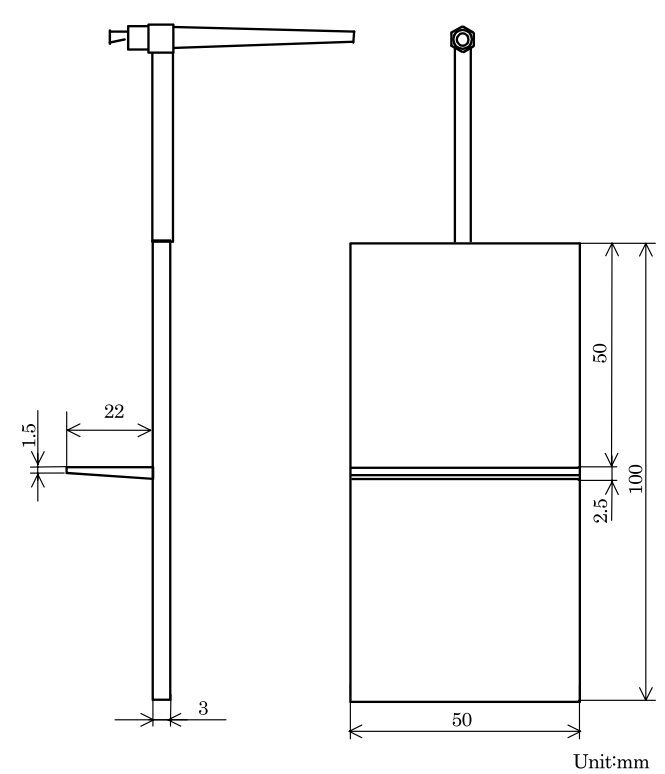

Fig. 1 The shape of injection molding plate with rib

不足を補う方法の一つとして内側にリブを設ける ${ }^{10)}$.また， リブを設けることで, リブ部を通過後した樹脂は流速が急 激に変化する場合があるため，偏肉形状にするなどの形状 変更が行われる ${ }^{14)}$. よって，本論文ではこのような，実部 品に生じる現象を単純モデルで再現するため, 平板, 偏肉, リブ付き平板を検討形状とした。本研究で用いた成形板形 状の一例として，リブ付き平板形状を図 1 に示す。天板部 (キャビティ部) はどの形状においても $50 \times 100 \mathrm{~mm}$ とし， 平板，リブ付き平板では成形板の板厚を $3 \mathrm{~mm}$ とした。一 方, 偏肉形状の場合, ゲート側を $3 \mathrm{~mm}$, 成形板端部側を $2 \mathrm{~mm}$ とした。リブ付き平板の場合, 成形板中央に $22 \mathrm{~mm}$ のリブを設け，抜き勾配を $1 / 22$ とした。

\section{2 供試材料および成形条件}

供試材料は結晶性材料であるポリプロピレン（日本ポリ プロ製 MA-1 B 以後, PP とする）を用いた。成形条 件は成形温度 $210^{\circ} \mathrm{C}$, 射出速度 $50 \mathrm{~mm} / \mathrm{s}$, 金型温度 $50^{\circ} \mathrm{C}$, 冷却時間 30 秒, 保圧 $29.2 \mathrm{MPa}$ とした。なお, 成形は型 締め力 $490 \mathrm{kN}$ のプリプラ式射出成形機（ソディックプラ ステック製 TR-50 S 2 A）を用いた.

\section{3 そり量測定方法}

形状要素がそり変形に与える影響を確認するため, 各形 状におけるそり量測定を行った。そり量はレーザー変位計 を用いて測定した.そり量測定箇所を図 2 に示す.レーザー 変位計は成形板のゲートを切り離した後, 定盤上に置いた 成形板の天板部にレーザーを照射し，その反射光によりそ り量を測定する。測定点は成形板の $\mathrm{x}, \mathrm{y}$ 方向へそれぞれ $10 \mathrm{~mm}$ 間隔でマーキングし, 各々の交点とした.よって 測定点は計 77 箇所となる．ここで，（0，0）の位置を A 点，(0, 50) の位置を B 点, $(0,100)$ の位置を C 点, $(100,50)$ の位置を D 点とする. 測定した結果は更に， A, B , Cの 3 点を基準点とし, 基準点より各々の点における変形量に 補正した.

\section{4 そり量測定結果および考察}

図 3 に各形状要素の天板部のそり量測定結果を示す.こ こで横軸は図 2 における $\mathrm{A}-\mathrm{C}$ 間を示す。また, 原点は $\mathrm{A}$ 


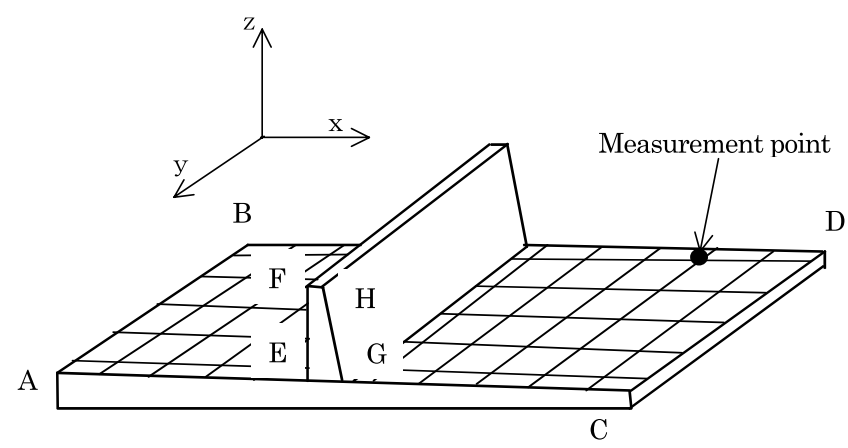

Fig. 2 The location of measurement of warpage

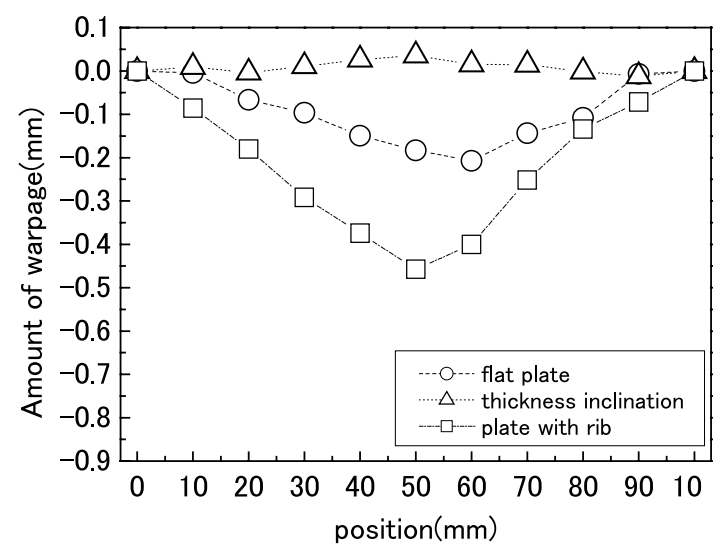

Fig. 3 The measured warpage profile from point A through $\mathrm{C}$ for 3 shapes

点を示し， $100 \mathrm{~mm}$ は C 点を示す.

そり量測定の結果, 他の形状と比較し, リブ付き平板で そり量は大きくなることがわかった. さらにリブ付き平板 のそり変形はリブを設けた箇所で最大そり量を示すことが わかった.リブ付き平板の樹脂流動は天板部（ $\mathrm{x}$ 方向）を 流れる樹脂とリブ（ $\mathrm{z}$ 方向）を流れる樹脂とに分かれる. また，リブ周辺部分では冷却速度差が発生していることが 予想される。このようにリブを設けることで分岐流の発生 （流動要因）や，成形板の各場所や層ごとで冷却速度差が 発生（熱的要因）し，そり量は大きくなったと考えられる. 一方，平板や偏肉形状の場合，流動方向は変化せず，場所 ごとでの冷却速度差も小さいため, そり量は小さくなると 考えられる。

次にリブ付き平板での熱的要因の影響を検討するため, 金型温度変更条件 $\left(30,50,80^{\circ} \mathrm{C}\right)$ でのそり量測定を行っ た。そり量測定結果を図 4 に示す.そり量測定結果より, 金型温度を高くすることで最大のそり量は大きくなること がわかった. また, 金型温度が $30^{\circ} \mathrm{C}$ と $50^{\circ} \mathrm{C}$ と比較し, $80^{\circ} \mathrm{C}$ の場合, 約 2 倍程度, そり量は大きくなることがわかった

これは金型温度を $80^{\circ} \mathrm{C}$ にすることで, 金型内での樹脂 が徐冷されることや金型温度が高いため, 離型直後から室 温まで更に徐冷 (型温： $80^{\circ} \mathrm{C} \rightarrow$ 室温： $23^{\circ} \mathrm{C}$ ) されることの 影響であると考えられる.

\section{3 . 成形板内に生じる物性値分布の測定}

前章の結果より, 形状要素ごとにそり量を測定した結果, リブ付き平板で，そり量が最も大きくなった.リブ付き平

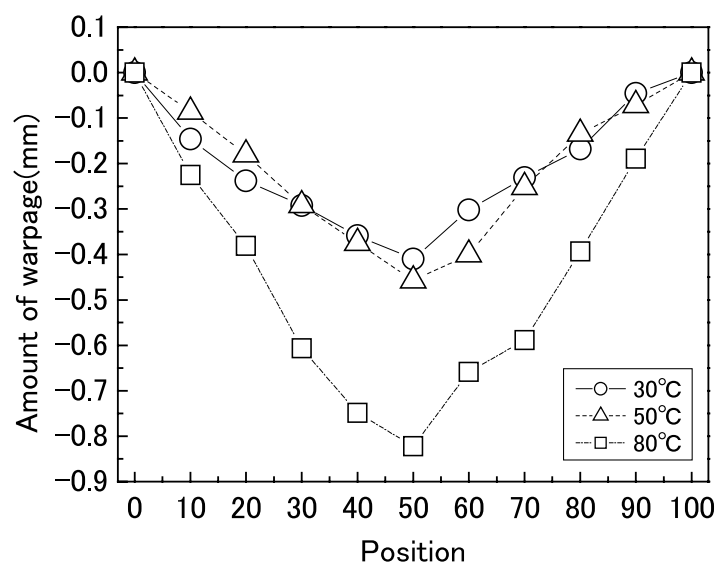

Fig. 4 The measured warpage profile from point A through $\mathrm{C}$ for 3 mold temperatures

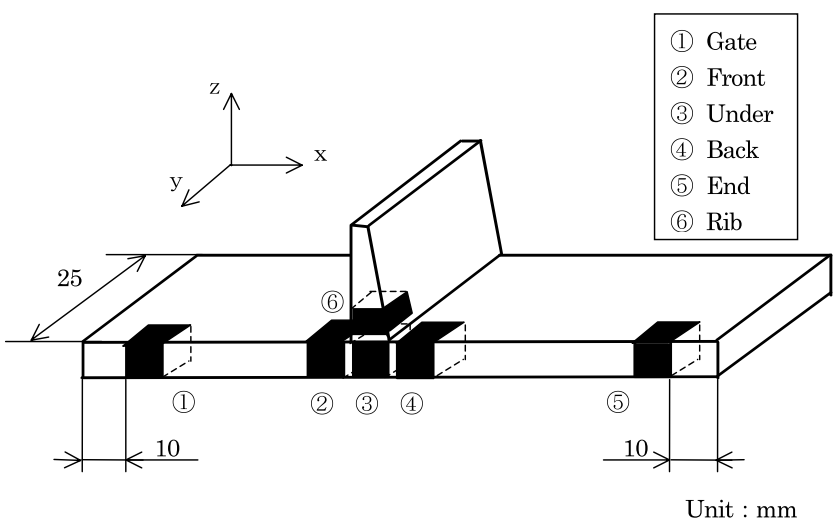

Fig. 5 Measurement locations for material poroperties

板の場合, リブを設けることで流動要因と熱的要因の両因 子の影響を受けそり量は大きくなったと考えられる。

本章ではリブ付き平板の各場所で物性值測定（線膨張係 数, 密度測定）を行うことでリブ付き平板のそり発生メカ ニズムの検討を行った。

\section{1 試験片作製方法および測定方法}

前章でのそり量測定結果より，リブ付き平板では分岐流 発生による影響（流動要因）と各場所で冷却速度の違いに よる影響（熱的要因）でそり量が大きくなると考えられる.

そこで，樹脂流動過程中に生じた分子鎖の配向等に起因 して発生する線膨張係数を測定することで流動要因の影響 を検討した。また，冷却速度差や収縮差の違い等の熱的要 因を検討するため，密度測定を行った．

本論文では, リブを設けることで線膨張係数や密度と いった物性值が場所により異なることが予想される。そこ で物性值測定用試験片は図 5 に示す通り, 計 6 箇所とした。 図 5 に示す通り, $3 \times 3 \times 3 \mathrm{~mm}$ のブロックを切り出した後, 測定面を仕上げるため，研磨機（マルトー製 ML-150 P） を用いて研磨した．試験片は研磨時に発生する摩擦熱が線 膨張係数や密度といった物性值に影響を与えないようにす るため, 流水により十分冷却しながら研磨した. なお, 各々 の試験片内での厚み分布は $\pm 20 \mu \mathrm{m}$ 以内, 試験片ごと厚 みの誤差は $\pm 5 \%$ 以内とした。 
線膨張係数は熱機械分析装置 (島津製作所製 TMA-50) を用い, $0.5 \mathrm{~g}$ の圧縮荷重を負荷しながら昇降温し, 温度 と熱ひずみの関係より線膨張係数を算出した. なお, 測定 は $\mathrm{x}, \mathrm{y}, \mathrm{z}$ の 3 方向とした（前章と同様に天板部の樹脂 流動方向を $\mathrm{x}$ 方向とした).

本論文では樹脂流動過程中に生じた分子鎖の配向等に起 因した線膨張係数の測定が目的である.よって，測定中の 昇温により，分子鎖の配向が緩和しないようにするため， 昇温範囲は $30^{\circ} \mathrm{C} \sim 70^{\circ} \mathrm{C}$ とした。 また，測定は $30 \sim 70^{\circ} \mathrm{C}$ ま で昇温することで熱的要因により発生した残留応力を除去 し，降温時のデータを用いて線膨張係数を算出した. よっ て, 線膨張係数の測定により各場所, 各方向の熱収縮が得 られる. 昇温速度は $1^{\circ} \mathrm{C} /$ 分とし，70〜 $40^{\circ} \mathrm{C}$ までの降温時 は $-1{ }^{\circ} \mathrm{C} /$ 分, $40 \sim 30^{\circ} \mathrm{C}$ までは $-0.5^{\circ} \mathrm{C} /$ 分の速度とした。

密度測定は密度勾配管（柴山科学機器製）を用いた。ま た，勾配液はエタノールー四塩化炭素により作製した。

\section{2 線膨張係数測定結果および考察}

図 6〜図 7 にリブ付き平板の金型温度が $80^{\circ} \mathrm{C}, 50^{\circ} \mathrm{C}$ の 場合の各場所における線膨張係数測定結果を示す。ここで, $\mathrm{x}$ 方向が天板部の樹脂流動方向を表す.

金型温度が $80^{\circ} \mathrm{C}$ の場合，どの方向の線膨張係数も場所 ごとで大きく変化する. 金型温度が $50^{\circ} \mathrm{C}$ の場合, どの場 所においても $\mathrm{y}, \mathrm{z}$ 方向の線膨張係数はほぼ一定となるが $\mathrm{x}$ 方向の線膨張係数は各場所で大きく変化する。これらの ことより, 金型温度を変更することで, 各方向の線膨張係 数は場所ごとで大きく変化し, 成形板には場所の違いによ る線膨張係数の分布が生じることがわかった。 これは前述 の通り，リブを設けることで分岐流が発生するなどの影響 を受けるためと考えられる。

一方，平板における金型温度 $80^{\circ} \mathrm{C} に お け る$ 線膨張係数 測定結果を図 8 に示す. 平板の場合, 各方向の線膨張係数 は各場所でほぼ一定であり, 場所の違いで線膨張係数は変 化しないことがわかった.

これらの結果から，リブ付き平板でそり量が大きくなる のは線膨張係数が場所ごとで大きく変化するためと考えら れ，このことはリブ付き平板のような複雑形状の射出成形 品に生じるそり変形は, 線膨張係数 (流動要因) が大きく 影響することを示唆している.

図 4 でのそり量測定結果より, そり変形はリブ設置位置 で最大值を示し，リブ下を境に対称なそり変形が生じてい る.よって，リブ付き平板でのそり変形はリブ下およびリ ブ前後での線膨張係数の違いが影響していると考えられる. 各場所, 各方向での線膨張係数がそり変形に与える影響は 今後の検討課題としたい.

\section{3 密度測定結果および考察}

リブ付き平板の密度測定結果を図 9 に示す。密度測定の 結果，金型温度を高くすることで密度分布は高密度側にシ フトする．また，リブ前（図 5 中の(2)）で最も密度が高く， リブ前では他の場所と比較し, 徐冷部分であったと推察さ れる.また，どの金型条件でも同じ傾向を示し，金型温度 変更により, 場所ごとでの密度差の傾向は変わらないこと がわかった. 金型温度を高くすることで成形板全体は徐冷 となり, 各場所の密度は高くなるが, 各場所での冷却速度 差(収縮差) は変化しないことを示唆していると考えられる.

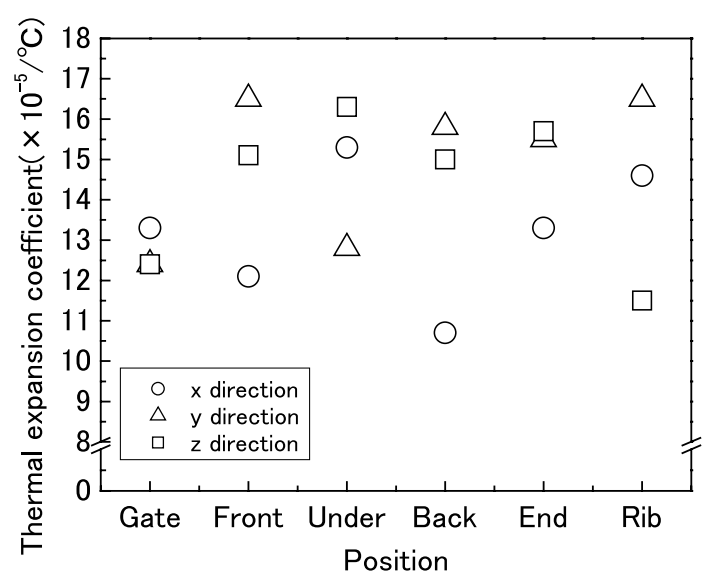

Fig. 6 Measurement result of thermal expansion coefficient in at the plate with $\operatorname{rib}\left(\right.$ at $\left.80^{\circ} \mathrm{C}\right)$

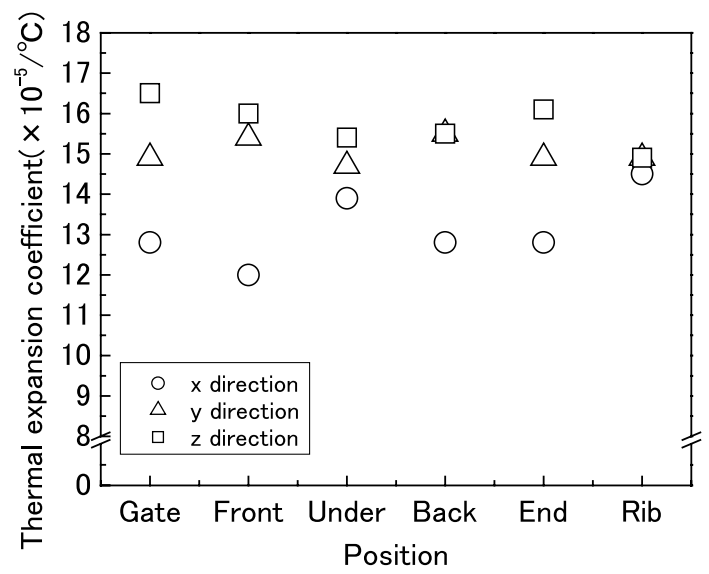

Fig. 7 Measurement result of thermal expansion coefficient at the plate with rib $\left(\right.$ at $\left.50^{\circ} \mathrm{C}\right)$

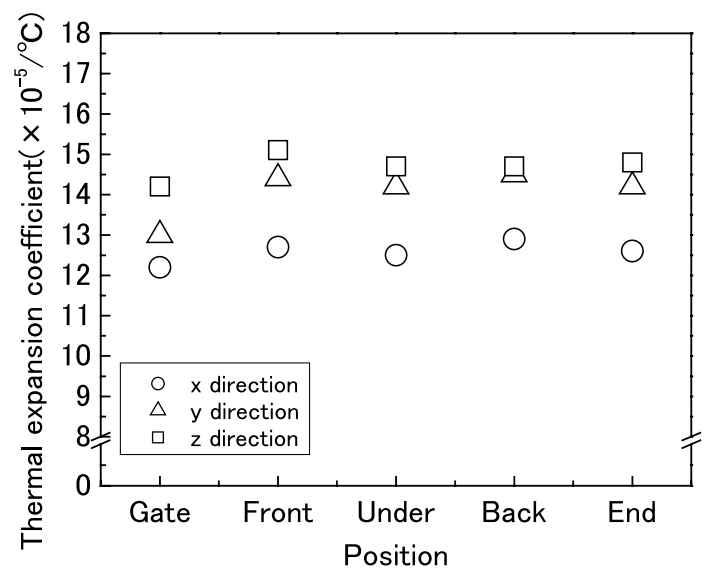

Fig. 8 Measurement result of thermal expansion coefficient for flat plate $\left(\right.$ at $\left.80^{\circ} \mathrm{C}\right)$

このことと前節との結果を合わせて考えた場合，金型温 度が $80^{\circ} \mathrm{C}$ の場合, $50^{\circ} \mathrm{C}$ と比較し, 成形板の場所ごとで線 膨張係数は大きく変化する (分布が大きくなる). 一方, 各場所での密度分布の大きさは金型温度に依存しない. よって，金型温度が $80^{\circ} \mathrm{C}$ におけるリブ付き平板でそり量 が大きくなった原因は場所ごとの線膨張係数分布が大きく 


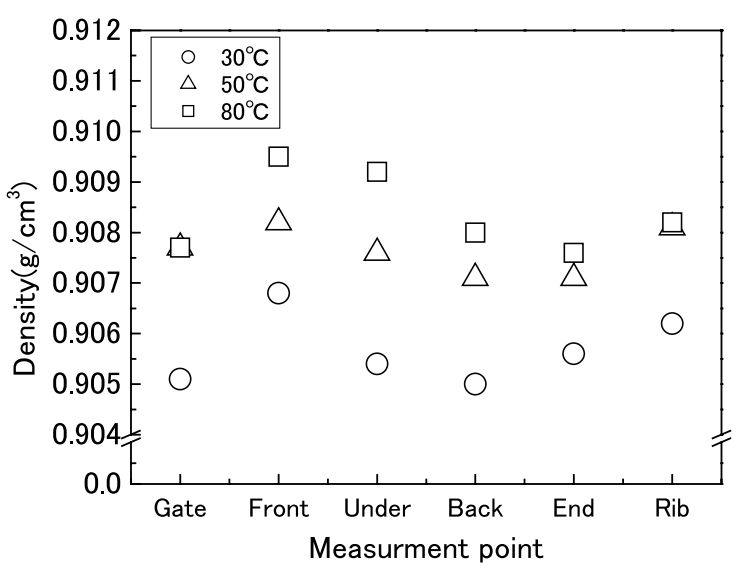

Fig. 9 Measurement result of density with respect to 3 mold temperatures (plate with rib)

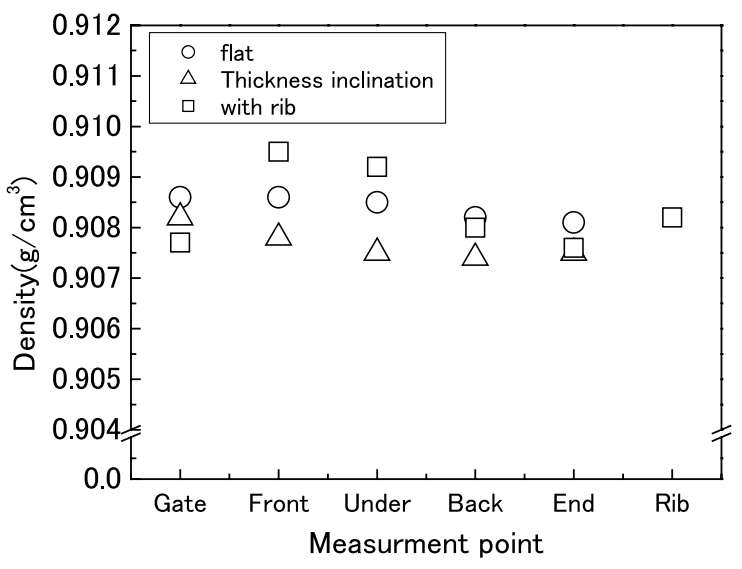

Fig. 10 Measurement result of density for 3 different of shapes $\left(\right.$ at $\left.80^{\circ} \mathrm{C}\right)$

変化したためと考えられる.

図 10 に各形状における金型温度 $80^{\circ} \mathrm{C}$ の密度測定結果を 示す. 図 10 より，そり量の小さい平板や，偏肉形状では 各場所での密度分布は小さいことがわかった。これは平板, 偏肉形状では成形板ごとで泠却速度差が発生しないためと 考えられる。一方，リブ付き平板の場合，天板部にリブが 設けられていることから，リブ周辺部（特にリブ前）では 冷却速度が異なり，密度分布が生じたと考えられる。

以上の結果より，リブ付き平板ではリブの影響により， 分岐流や冷却速度差が生じ，そり量は大きくなったと考え られる。また，形状により流動要因や熱的要因がそり変形 に与える影響は変化することを確認した。

本結果は本研究で用いた材料㧍よび成形条件範囲内での 結果であり, 他の材料では, 各因子がそり変形に与える寄 与度は異なり，そり量も変化すると考えられる。

\section{4. 可視化による樹脂流動挙動観察}

前章までの結果より，リブ付き平板を用いた（金型温度 $\left.80^{\circ} \mathrm{C}\right)$ 場合, 場所ごとで線膨張係数の分布が生じているこ とがわかったこれはリブを設けることで樹脂流動方向に 違いが生じるためと考えられる.

本章ではリブ付き平板（金型温度 $80^{\circ} \mathrm{C}$ ）における可視

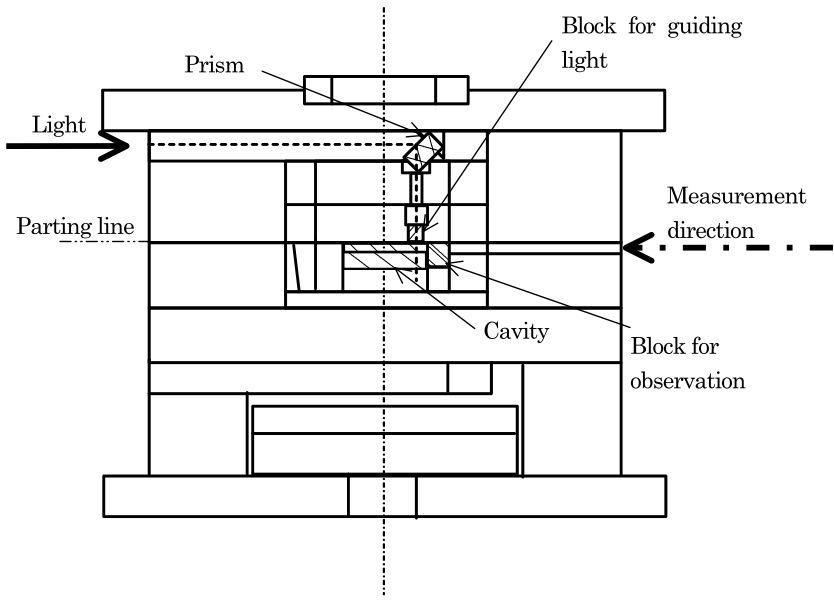

Fig. 11 Structure of visualization mold

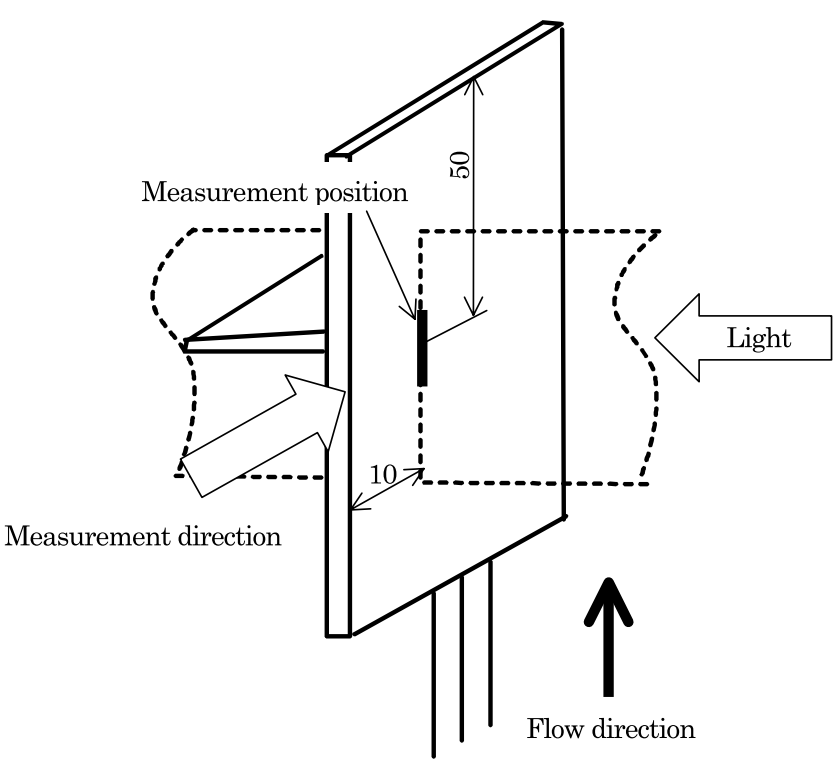

Fig. 12 Measurement position of resin flow velocity by visualization experiment

化実験により，リブ周辺の樹脂流動挙動観察を行うことで 樹脂流動方向の確認や樹脂流速の測定を行った。

\section{1 可視化観察方法 ${ }^{8}$}

可視化観察用金型は固定側に光透過用アクリルブロック， キャビティ側面に観察用ブロックを組み込んだ金型である (図 11). 樹脂流動挙動の観察は光切断法を用いて行った. 光切断法は八ロゲンランプを用い，キャビティ側面よりス リットを介したシート上の光を照射させる．照射された光 はプリズムを介し，角度を $90^{\circ}$ 変換され，光透過用ブロッ クを透過し，成形板に直角に照射する（図 12）.

また，樹脂流速は PIV 法（粒子追跡画像流速分布測定 法)により算出した。トレーサーとして銅粉 (平均粒径 150 $\mu \mathrm{m} ）$ を樹脂内に混入させ，成形時の樹脂流動挙動を高速 度カメラにて撮影した。樹脂流速は撮影した画像を用い， 銅粉の移動量と画像のコマ数から算出した（図 13).

成形時，キャビティ内の樹脂は高速で充填される. よっ て, 高速度カメラの 1 秒間当たりのコマ数が少ない場合, 1 コマ間での銅粉の移動量は大きくなり，正確な樹脂流速が 


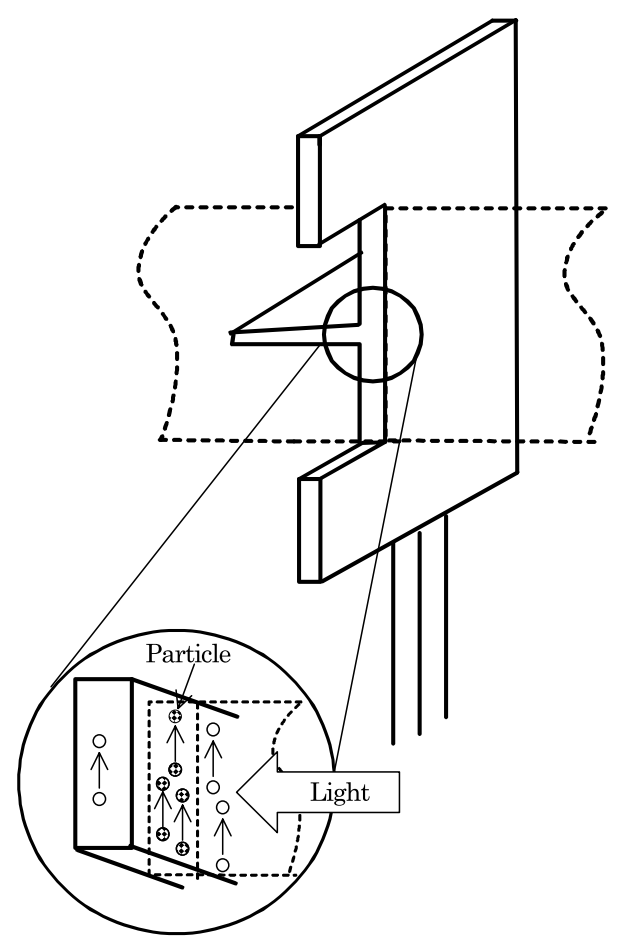

Fig. 13 Measurement of resin flow velocity distribution in thickness direction using PIV method

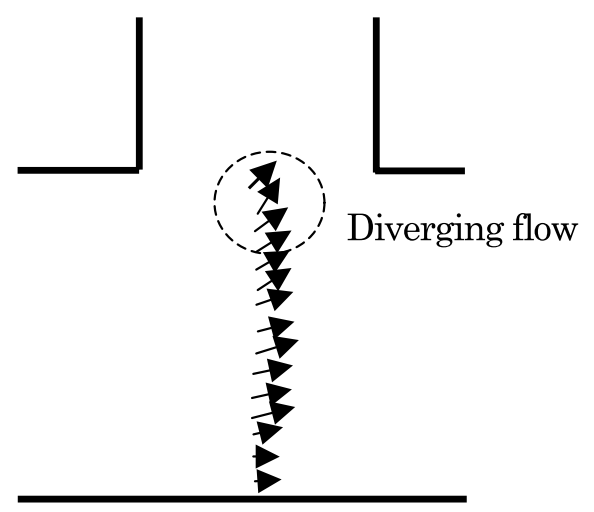

Fig. 14 Vector of resin flow when flow front arrives under rib

測定出来ない，そこで，最大 5000 コマ/秒まで撮影可能な 高速度カメラ（ナック製 MEMRECAM RX-6）を用い, 撮影を行った。また，光源は $500 \mathrm{~W}$ のハロゲンランプを 用いた。なお，測定箇所はリブ前，下，後（図 5 中の(2), (3), (4)）の 3 箇所とした.

\section{2 樹脂流動方向の検討}

図 14〜16にリブ下（図 5 中の(3) での樹脂流動のベク トルを示す。ここで, 樹脂のフローフロントがリブ下に到 達した場合を 0.0 秒とした. 0.0 秒の場合, 天板部と平行 に流れる樹脂と天板部とリブ部への分岐流を確認した (図 14)．0.03 秒後では 1) 天板部と平行に流れる流動，2) リブ部を流れる流動，3）天板部とリブ部を分岐する流動 の 3 種類の流動が存在することがわかる（図 15）.

更にリブ部の充填が完了後では天板部の流動と共にリブ

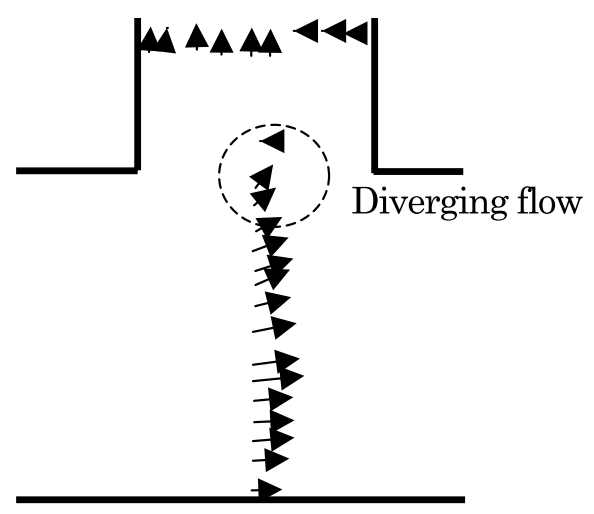

Fig. 15 Vector of resin flow after 0.03 seconds

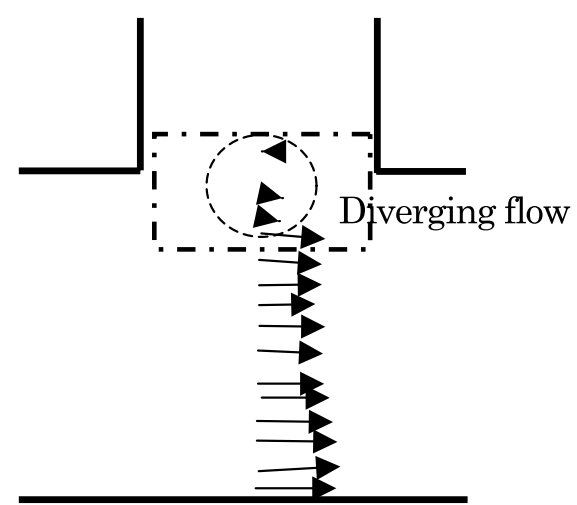

Fig. 16 Vector of resin flow when rib is filled

部の付け根部分で微少な分岐流が発生していることを確認 した（図 16）.

これは，リブ部の付け根部分では冷却速度が遅いためと 考えられる, 他の部分と比較し, リブ部の付け根部分は金 型に接している面が少なく, リブ部の充填が完了後も樹脂 は固化していないため, 微少な分岐流が発生したと推察さ れる。

\section{3 リブ前後での樹脂流速測定}

図 17 にリブ前後（図 5 中の(2)，(4)）の樹脂流速測定結 果を示す。ここでは, リブ前とリブ後の樹脂流速を定点観 察することで各々の場所での樹脂流速変化を測定した．こ こでも，前節と同様に 0.0 秒は樹脂のフローフロントがリ ブ下に到着した時間となる。

樹脂流速測定の結果，リブ前（図 5 中の(2) では固化層 の成長と共に流路が狭まり，この流路の狭まりによって， 樹脂流速は増加することを確認した（図 $17 \mathrm{a} ） \rightarrow \mathrm{b}$ )).

一方， 0.5 秒後のリブ後（図 5 中の(4)）の流速はリブ前 と比較し，低速であることがわかった（図 $17 \mathrm{~b})$ ). 更に， リブ部の充填完了後（図 $17 \mathrm{~b} ） \rightarrow \mathrm{c}$ ) ) では流速が増加し, リブ前と同等の樹脂流速となる.

リブ下（図 5 中の(3)）での樹脂流動は天板部とリブ部と の分岐流となるため, リブ後での流速が低下すると考えら れる.リブ部の充填が完了することで，リブ下での樹脂流 動が平行流となるため, 場所による流速の相違が無くなる と考えられる.

このようにリブ前後では 1）分岐流による流動方向の変 


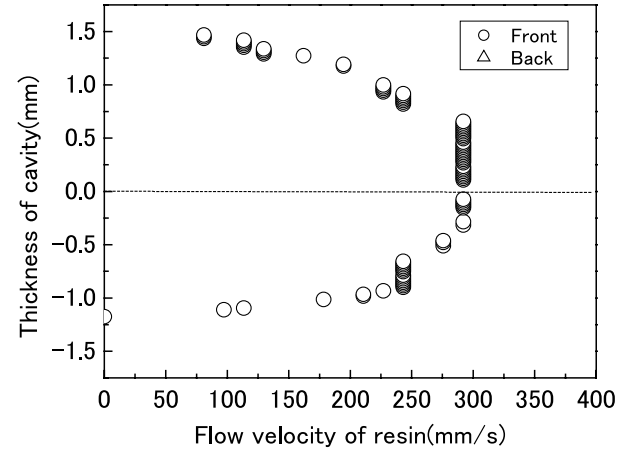

a) $0 \mathrm{sec}$

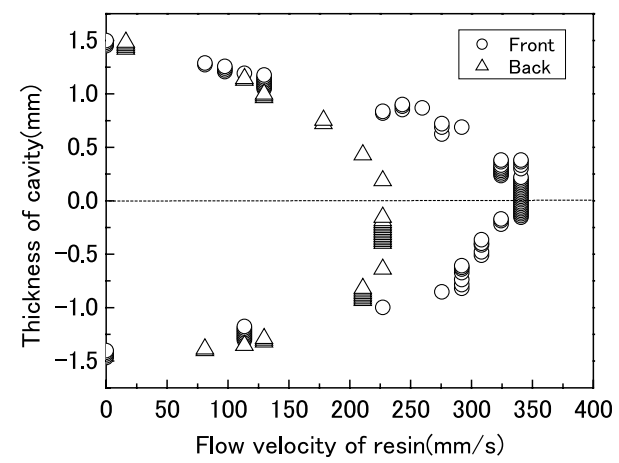

b) $0.5 \mathrm{sec}$

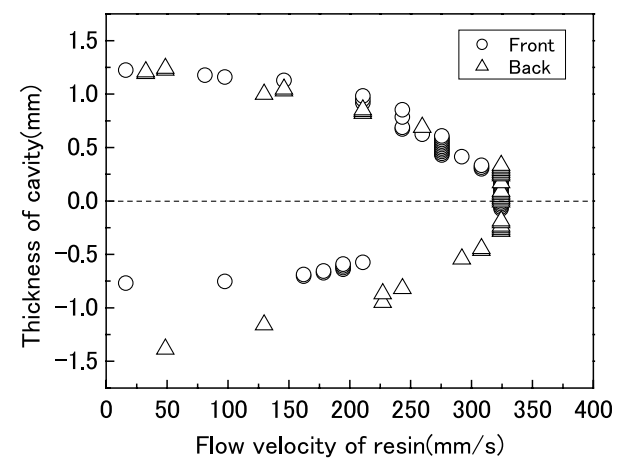

c) $0.65 \mathrm{sec}$

Fig. 17 The measurement result of resin flow velocity distribution

化，2）リブ下での微少流動の発生，3）充填中の場所ごと での樹脂分布と流速の変化などが発生することがわかった。 リブ付き平板ではこのような複雑な流動の影響により，場 所ごとで線膨張係数が大きく変化すると推察される.

一方，平板の場合の樹脂流動はキャビティ内で対称な ファウンテンフロー（リブ付き平板におけるリブ部充填完 了後の天板部の流れと同様）となり ${ }^{8}$, 場所により流動方
向や流速は変化しないと考えられ，場所ごとの線膨張係数 の分布は小さいと考えられる。

\section{5.結言}

本論文では実部品で構成される代表的な形状要素を抽出 し，各々の形状要素に分割したテストピースを用い，射出 成形品に生じるそり発生メカニズムの検討を行い，以下の ことを明らかにした。

1 ）種々の形状要素に分割し，そり量を測定した結果，リ ブ付き平板で最もそり量が大きくなる.

2）リブ付き平板ではリブを設けることで，場所ごとで線 膨張係数の分布や密度分布は大きくなるため，そり量 が大きくなる。

3 ）複雑形状におけるそり変形は熱的要因と流動要因によ り発生し，形状によりその影響度合いは変化する。

4）リブ部周辺の樹脂流動は分岐流の発生，微少流動の発 生，樹脂流速の増大等の複雑な流動が発生する。この ことが要因の一つとなり, 場所ごとで線膨張係数の分 布は大きくなる.

\section{参 考 文 献}

1 ）千坂浅之助：射出成形技術入門 基礎と応用， 185 (1992)，シグマ出版

2 ) 多田和美：材料システム，13，31(1994)

3 ）日本塑性加工学会編：流動解析 プラスチック成 形，90(2004)，コロナ社

4 ）米谷 茂, 広瀬英典：材料， $29(322) ， 42(1980)$

5 ）新保 實, 宮野 靖：材料システム，13，71(1994)

6 ) Kikuchi, H.and Koyama, K : Polym. Eng. Sci., 34, 1411 (1994)

7 ）瀬戸雅宏, 佐藤和人, 山部 昌：成形加工, 16(8), 548 (2004)

8 ）瀬戸雅宏, 田中 克, 山部 昌：成形加工, 15(5), 363 (2003)

9 ）高原忠良，杉本好男：成形加工，15(3)，208(2003)

10）竹内 淳：本田技報， 12(1)，183(2000)

11）一柳高時, 中 裕之, 剣持加津衛：日本機械学会論文 集 (A 編)，53(485)，148(1987)

12）山田和慶, 西郷栄人, 田中宏尚：成形加工, 14(8), 496 (2002)

13）舘山弘文, 土屋淳志, 小山清人：成形加工, 15(10), 694 (2003)

14）宮崎 寿：成形加工，17 (5)，322（2005） 